\title{
What is happening to our Lagoons? The example of Butuah Lagoon in Ghana
}

\author{
Nehemiah T. Odjer-Bio $\cdot$ Ebenezer J. D. Belford • \\ Michael Ansong
}

Received: 22 September 2014/ Accepted: 12 February 2015/Published online: 22 February 2015

(c) The Author(s) 2015. This article is published with open access at Springerlink.com

\begin{abstract}
Lagoons are among the most important ecosystems in the world. To find out how activities around lagoons affect their physical and chemical properties, we assessed the physicochemical properties and concentrations of seven heavy metals from samples of sediments, Tilapia fish and water of Butuah Lagoon in Ghana, as an example. The lagoon was slightly alkaline with a fairly constant temperature but increased dissolved salts and inorganic materials that have resulted in higher electric conductivity than permissible for aquatic life. There was an indication of a large quantity of organic waste in the lagoon which reflected as high biological and chemical oxygen demand. We also recorded extremely high concentrations of oil and grease that negatively correlated with all physicochemical parameters measured. Lead $(\mathrm{Pb})$ concentration in the three media was higher than the permissible limits while Zinc $(\mathrm{Zn})$ and Cadmium (Cd) were higher in two except the water sample. Arsenic (As) concentrations were higher than the permissible limits only in the sediments. There is a significant anthropogenic impact on the lagoon, with the midstream having extremely high degree of contamination of most of the metals. The main pollutant in the sediment was Cadmium with high enrichment factor
\end{abstract}

N. T. Odjer-Bio · E. J. D. Belford

Department of Theoretical and Applied Biology, Kwame

Nkrumah University of Science and Technology, Kumasi, Ghana

N. T. Odjer-Bio $(\square)$

Abokobi, P. O. Box AK 46, Accra, Ghana

e-mail: Nehe502001@yahoo.com

M. Ansong

Environmental Futures Research Institute, Griffith University, Gold Coast, Queensland 4222, Australia and geo-accumulation index value. Although, the concentrations of most metals in the fish were below the highest permissible level recommended, the higher levels in the water and sediment are of concern. It will be necessary to have a long-term monitoring programme for Butuah Lagoon to prevent it from further deterioration. Also, as bioaccumulation is a gradual process, having such programmes will prevent the risk of people eating and using fish and water contaminated with such deleterious metals.

Keywords Atomic absorption spectrophotometer . Environmental monitoring · Heavy metal pollution · Pollution index . Water quality analysis - Bioaccumulation

\section{Introduction}

Lagoons are considered one of the most important ecosystems globally [1-3]. They provide lots of ecosystem services and functions, including habitat and nursery sites for fish species, reference stations for a variety of migratory birds, and food and water sources for some human communities [2]. Their continual existence is recognised, therefore, as essential for the survival of many organisms, including humans $[2,3]$.

Most lagoons are polluted, mainly from anthropogenic waste input, because they lack proper watershed management strategies [1, 2, 4]. Among the major pollutants recorded in different lagoons around the world are heavy metals [4-6]. Heavy metals are very harmful, due to their $[1,2,4]$ toxicity, persistence and deleterious impact on aquatic life and human health $[5,6]$. Currently there are no well-established mechanisms to remove and eliminate heavy metals from the human body. The presence of heavy 
metals in aquatic systems such as lagoons, therefore, calls for greater concern $[1,2,7]$.

Butuah Lagoon in New Takoradi in the Western Region of Ghana is one of the three significant lagoons in the Sekondi-Takoradi Metropolis [8, 9]. The Lagoon serves as a breeding ground for some marine species and is inhabited by a great diversity of species including the threatened fish species Sarotherodon melanotheron, Liza falcipinnis, Oreochromis niloticus, the crabs Callinectes amnicola, Goniopsis cruentata, and rear mangroves Rhizophora mangle, Laguncularia racemosa, Avicennia portulacastrum [9]. Butuah Lagoon is also a protected area for fishing with the majority of people in New Takoradi depending on it for their livelihood [8].

A substantial part of Butuah Lagoon is occupied by settlements and industries, which have led to the construction of several drainages, refuse dumps, defecating grounds, animal husbandry, and other intense activities such as fish landing sites around the lagoon [8,9]. This has resulted in a large tract of wetland near the lagoon, which serves as a buffer zone against flood, which has been heavily polluted. High abundance of blue-green algae in the Lagoon, an indication of high levels of nutrients such as nitrogen and phosphorus, for example, has also been reported [9]. Similarly, the 26 September 2011 edition of the Ghana national paper, Daily Graphic, reported the death of more than 40,000 fishes in the lagoon with people who ate some of the fish sent to hospitals due to stomach running and dehydration. According to the Chronicle Newspaper of August 22012 fishing and farming activities in and around Butuah Lagoon were also recently banned by the SekondiTakoradi Metropolitan Assembly (STMA) due to pollution of the lagoon with paraquat toxicity.

Despite its importance and the threat it currently faces, research on the Butuah Lagoon is limited and no published study was found on the levels of heavy metals in the lagoon. The aim of this study was, therefore, to find out to what extent do the activities going on around the Lagoon affect its physical and chemical properties [1, 2, 7-9]. Specifically, the study is based on the following questions: (1) do the physicochemical properties of water from the Lagoon fall within the accepted range for aquatic life? (2) What is the level of Arsenic (As), Copper $(\mathrm{Cu})$, Lead $(\mathrm{Pb})$, Zinc $(\mathrm{Zn})$, Iron $(\mathrm{Fe})$, Cadmium $(\mathrm{Cd})$ and Mercury $(\mathrm{Hg})$ in the sediments, Tilapia fish and water from the Lagoon? (3) Do the concentrations of heavy metals recorded in the sediment and water samples differ among the sampling stations? and (4) what is the degree of heavy metal pollution in the sediment as indicated by assessment index? The study provides information that could help in the development of management strategies and create awareness to other stakeholders.

\section{Materials and methods}

Study area

Butuah Lagoon $[8,9]$ has an estimated area coverage of $\sim 86,400 \mathrm{~m}^{2}$ and total area of natural boundary of $\sim 423,500 \mathrm{~m}^{2}$ of which industrial activities and settlement cover $\sim 9 \%$ of the total area (Fig. 1) [9]. The industries include oil companies, wood processing companies, household utility manufacturing company, cocoa processing company, steel casting company, and a number of automobile fitting shops. The Lagoon has an equatorial climate as the metropolis in which it is located. The rainfall in the metropolis is bi-modal, with the major season occurring between March and July and the minor season occurring between August and November. The mean annual rainfall is about $1,380 \mathrm{~mm}$, covering an average of 122 rainy days.

\section{Sampling}

Three sampling stations were randomly selected in the lagoon to collect samples of water and sediment. The sampling stations were within $04.90500^{\circ} \mathrm{N}, 001.74870^{\circ} \mathrm{W}$ (downstream), $04.91176^{\circ} \mathrm{N}, 001.75003^{\circ} \mathrm{W}$ (midstream) and $04.91522^{\circ} \mathrm{N}, 001.75355^{\circ} \mathrm{W}$ (upstream) (Fig. 1). Sampling was done once in a month, from December 2011 to March 2012. In situ measurement of temperature was done in each station during each sampling period using BRANNAN $76 \mathrm{~mm}$ Immersion Thermometer.

Tilapia fish (Oreochromis niloticus) samples were randomly collected from different parts of the lagoon. They were caught with mesh net. Water samples were collected from a mean depth of $50 \mathrm{~cm}$ with $500-\mathrm{mL}$ acid-washed low-density polyethylene bottles from the three stations. Samples were collected at least $30 \mathrm{~cm}$ far from the border, from natural or artificial obstacles to avoid contamination. They were then acidified with $5.0 \mathrm{ml}$ of $50 \% \mathrm{HNO}_{3}$. Sediment samples were collected with the aid of an Ekman Grab from at least $10 \mathrm{~cm}$ of the lagoon bed and stored in polyethylene bags. Samples (water, fish and sediments) were kept in ice chests at about $4{ }^{\circ} \mathrm{C}$ and transported to the laboratory for analysis. The samples were prepared in the laboratory for the physicochemical properties and heavy metal concentration determined.

\section{Laboratory analysis}

Total Dissolved Solids (TDS) and Conductivity (COND) were determined using the Conductivity Meter EH CLM 381 model; $\mathrm{pH}$ was determined using JENWAY $3505 \mathrm{pH}$ Meter with accuracy of $\pm 0.02 \mathrm{pH}$ while the Mohr Method of Argentometric Titration was employed for the analysis 
Fig. 1 Map of Butuah Lagoon showing the three sampling points

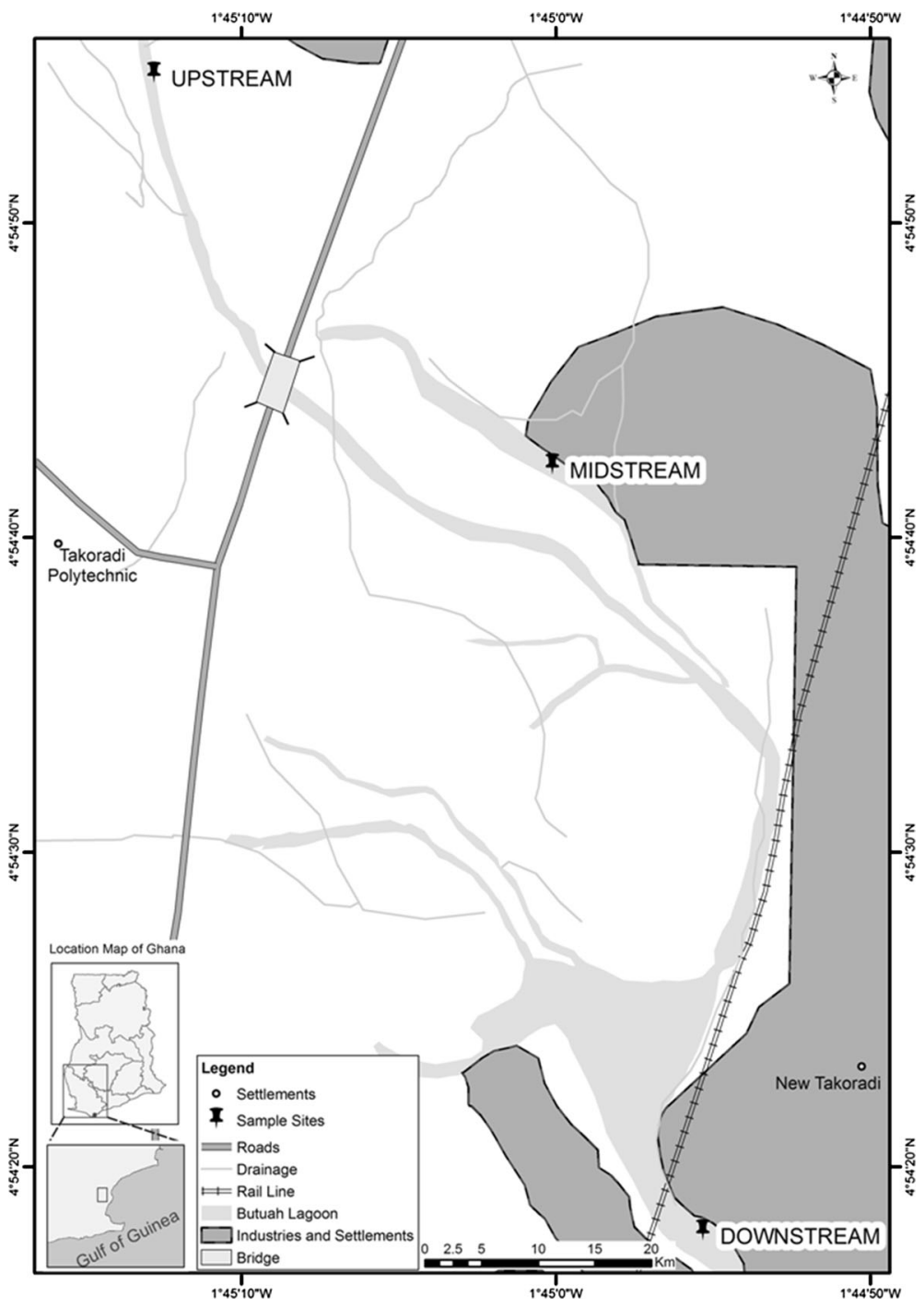

of chloride (Chlor). The Partition Gravimetric Method was used in the determination of oil and grease, biological oxygen demand (BOD) was determined using the dilution method and chemical oxygen demand (COD) determined using the Open Reflux Method [10].

Sediment samples were air dried to a constant weight, and then ground and homogenized in a mortar to a fine powder and gently sieved. Fish samples were washed thoroughly with distilled water to remove debris and the muscles removed using a stainless steel knife. One gram of the homogenized sediment and fish samples were weighed into separate $50-\mathrm{ml}$ digestion tube. Ten (10) $\mathrm{ml}$ of the diacid $\left(\mathrm{HNO}_{3}-\mathrm{HClO}_{4}\right)$ in the ratio (9:4) was then added to each subsample. Each mixture was heated until the red $\mathrm{NO}_{2}$ fumes ceased and white fumes were produced. For the water samples, $100 \mathrm{ml}$ of each were measured and transferred into separate digestion tubes. Ten (10) $\mathrm{ml}$ of $50 \% \mathrm{HNO}_{3}$ was added to each of the samples and then heated on a hot plate until white fumes were produced [11]. The digested samples were allowed to cool and were washed with distilled water and filtered for heavy metal analysis. Analysis of 10 subsamples from each sampling site was done for each month.

Atomic Absorption Spectrophotometer (AAS 220 model) was used in determining the total concentrations of $\mathrm{Pb}, \mathrm{Cd}, \mathrm{Cu}, \mathrm{As}, \mathrm{Fe}$ and $\mathrm{Zn}$ while the Automatic Mercury Analyzer (Model HG 6000) equipped with a mercury lamp at a wavelength of $253.7 \mathrm{~nm}$ was used in determining the concentration of $\mathrm{Hg}$. All samples for analysis were accompanied by blanks at one blank per 10 samples and replicate analyses were conducted on the samples to evaluate precision of the analytical techniques.

\section{Assessment of sediment contamination}

The degree of metal pollution in the sediment was assessed using the Enrichment Factor (EF) [12], Contamination factor $\left(C_{\mathrm{f}}\right)$ and Modified degree of contamination $\left(m C_{\mathrm{d}}\right)$ $[13,14]$, Tomlinson pollution load index (PLI) [15], and 
geo-accumulation index (I-geo) [16]. A pre-industrial baseline concentration of heavy metals for the area could not be obtained; therefore, the recommended composition of the upper continental crust by Rudnick, Gao [17] was used for all the index calculations.

\section{Contamination factor $\left(C_{f}\right)$}

Contamination factor $\left(C_{\mathrm{f}}\right)$ reflects the metal enrichment in the sediment as it accounts for the element based on the background (reference) concentration [13, 14]. It is calculated as the ratio of sediment metal content at a given station to the background metal concentration [14] as:

$C_{\mathrm{f}}=M_{\mathrm{x}} / M_{\mathrm{b}}$

where $M_{\mathrm{x}}$ and $M_{\mathrm{b}}$ refer to the mean concentration of pollutant in contaminated and pre-industrial 'baseline' sediments, respectively. Depending on the magnitude, $C_{\mathrm{f}}$ is rated as 'low' $(\leq 1)$, 'moderate' (1-3), 'considerable' (3-6), or 'very high' $(>6)[14]$.

\section{Modified degree of contamination $\left(m C_{d}\right)$}

The Modified degree of contamination $\left(m C_{\mathrm{d}}\right)$ is a generalized form of the degree of contamination by Hakanson [14], which is the sum of all contamination factors $\left(C_{\mathrm{f}}\right)$ for the lagoon. The $m C_{\mathrm{d}}$ on the other hand divides the sum of all the $C_{\mathrm{f}}$ 's for a given set of estuarine pollutants by the number of analysed pollutants [13]. Thus,

$m C_{\mathrm{d}}=\left(C_{\mathrm{fi}}+\ldots \ldots C_{\mathrm{fn}}\right) / n$

where $C_{\mathrm{f} i}$ and $C_{\mathrm{f} n}$ are the contamination factors of the $i$ th and $n$th element (or pollutant) and $n$ is number of analysed elements.

An estuarine sediment with $m C_{\mathrm{d}}<1.5$ has nil to very low degree of contamination, $1.5 \leq m C_{\mathrm{d}}<2$ low, $2 \leq m C_{\mathrm{d}}<4$ moderate, $4 \leq m C_{\mathrm{d}}<8$ high degree, $8 \leq m C_{\mathrm{d}}<16$ very high, $16 \leq m C_{\mathrm{d}}<32$ extremely high, and $m C_{\mathrm{d}} \geq 32$ ultra-high degree of contamination [13].

\section{Tomlinson pollution load index (PLI)}

The PLI is a summative indication of the level of heavy metal pollution. It could be for a given sampling station (PLI) or for the entire estuary $\left(\mathrm{PLI}_{\mathrm{E}}\right)$. PLI is calculated from the $C_{\mathrm{f}}$ of each of its constituent samples while $\mathrm{PLI}_{\mathrm{E}}$ from the PLI of each station [15].

$$
\begin{aligned}
\mathrm{PLI} & =\left(C_{\mathrm{f} 1} \times C_{\mathrm{f} 2} \times C_{\mathrm{f} 3} \times \cdots \times C_{\mathrm{f} n}\right)^{1 / n} \\
\mathrm{PLI}_{\mathrm{E}} & =\left(\mathrm{PLI}_{\text {station } 1} \times \mathrm{PLI}_{\text {station } 2} \times \mathrm{PLI}_{\text {station } 3} \times \cdots \times \mathrm{PLI}_{\text {stationn }}\right)^{1 / n}
\end{aligned}
$$

where $n$ is the number of the constituent samples or station, $C_{\mathrm{f}}$ is the contamination factor of the heavy metals at the stations, and PLI $\mathrm{I}_{\text {stationn }}$ is the PLI for sample stations $n$. PLI or $\mathrm{PLI}_{\mathrm{E}}$ value of zero indicates perfection, a value of one means only the baseline levels of pollutants are present, and values above one indicate progressive deterioration of the sample station or estuarine quality [15].

\section{Enrichment factor $(E F)$}

Enrichment factor (EF) was used to differentiate the metal source as anthropogenic or naturally occurring [12] as it normalizes measured heavy metal content with respect to a sample reference metal [12]. We used Fe as the reference metal as it usually has a relatively high natural concentration and does not usually get into estuarine sediments from anthropogenic sources. Enrichment factor was calculated as:

$\mathrm{EF}=\left[\left(M_{\mathrm{x}} / \mathrm{Fe}_{\mathrm{x}}\right)_{\text {sediment }} /\left(M_{\mathrm{b}} / \mathrm{Fe}_{\mathrm{b}}\right)_{\text {earth'scrust }}\right]$

where $M_{\mathrm{x}}$ and $\mathrm{Fe}_{\mathrm{x}}$ are the sediment sample concentrations of the heavy metal and $\mathrm{Fe}$ while $M_{\mathrm{b}}$ and $\mathrm{Fe}_{\mathrm{b}}$ are their concentrations in a suitable background or baseline reference material. EF of one implies no enrichment, $<1$ depletion, and $>1$ enriched relative to the average earth's crust [12].

\section{Geo-accumulation index $\left(I_{\text {geo }}\right)$}

Geo-accumulation index $\left(I_{\text {geo }}\right)$, which measures the enrichment of metal concentrations above background or baseline concentrations [16] was also used to assess the sediment quality as:

$I_{\text {geo }}=\log _{2}\left[C_{i} /\left(1.5 B_{i}\right)\right]$

where $C_{i}$ is the measured concentration of the examined metal $i$ in the sediment, and $B_{i}$ is the background or reference value of the metal $i$. A factor of 1.5 is used because of possible variations in background values for a given metal in the environment as well as very small anthropogenic influences. $I_{\text {geo }} \leq 0$, class 0 , unpolluted; $0<I_{\text {geo }} \leq 1$, class 1 , from unpolluted to moderately polluted; $1<I_{\text {geo }} \leq 2$, class 2 , moderately polluted; $2<I_{\text {geo }} \leq 3$, class 3 , from moderately to strongly polluted; $3<I_{\text {geo }} \leq 4$, class 4 , strongly polluted; $4<I_{\text {geo }} \leq 5$, class 5 , from strongly to extremely polluted; and $I_{\text {geo }}>5$, class 6 , extremely polluted [16].

Statistical analysis

To determine if the concentrations of metals recorded in the sediment and water samples differed among the sampling stations, a Linear Mixed Model was applied. The concentration of the heavy metals was treated as the dependent variable while sampling station and dates of 
sampling were the independent variables. Sampling station was considered a fixed factor while date of sampling and their interaction were treated as random variables. The Bonferroni correction was used to determine the contrast between the three sampled stations. All the analyses were done in SPSS version 21, with the $p$ value set at 0.05 .

\section{Results and discussion}

Do the physicochemical properties of Butuah Lagoon fall within the accepted range for aquatic life?

The lagoon was slightly alkaline, with mean $\mathrm{pH}$ of $8.0 \pm 0.2$ (Table 1), which falls within the recommended range of 6.0-9.0 [18]. It had a fairly constant temperature with mean of $30.1 \pm 0.1{ }^{\circ} \mathrm{C}$ suitable for tilapia production [19]. The electric conductivity of the Lagoon was higher than permissible for aquatic life, with a mean of $2667.3 \pm 285.1 \mu \mathrm{S} / \mathrm{cm}[18,20]$. There was also a high level of total dissolved substance (TDS), with a mean of $1333.8 \pm 142.6 \mathrm{mg} / \mathrm{L}$, above the recommended level by the US EPA for aquatic life [18]. The results indicate increased levels in dissolved salts and inorganic materials in the lagoon [20, 21]. For example, the concentration of chloride in the Lagoon was very high with a mean of over $5000 \mathrm{mg} / \mathrm{L}$ (Table 1) which is above the maximum concentration of $1200 \mathrm{mg} / \mathrm{L}$ [37] and chronic toxicity tests indicate that aquatic organisms can adversely be affected at concentrations ranging from 735 to $4681 \mathrm{mg} / \mathrm{L}$ [39] even though sea water mixing could have accounted for the higher values recorded in the downstream and was positively correlated $(p<0.05)$ with conductivity, TDS and temperature (Table 2). These dissolved salts and inorganic materials may be from activities including the discharge of wastewater high in salts, brine waters from oil production activities and overuse of fertilizers [20,21]. The dissolved substance might also be coming from the sea, as the lagoon is sometimes opened for a relatively short period of time during the rainy season [9].

The mean concentrations of BOD $(80.5 \pm 5.6 \mathrm{mg} / \mathrm{L})$ during the sampling period was positively correlated with COD $(239.47 \pm 18.5 \mathrm{mg} / \mathrm{L})$ (Table 2). Unpolluted waters typically have a BOD value of $2 \mathrm{mg} / \mathrm{L}$ while those receiving wastewaters may have values up to $10 \mathrm{mg} / \mathrm{L}$ or more [20]. The high BOD recorded in the current study is thus an indication of a large quantity of organic waste in the lagoon. This may possibly be from the numerous inputs of domestic wastewater and the increased dumping of refuse along the banks [9], particularly at the downstream, which recorded the highest values. High levels of BOD could result in reduced dissolved oxygen available for other aquatic organisms, which could lead to change in the ecological structure and dynamics of the benthic communities as high diversity of species are replaced with a few low-oxygen-tolerant organisms [22].

Table 1 Mean values of physicochemical parameters measured from water sample along three randomly selected stations in Butuah Lagoon

\begin{tabular}{|c|c|c|c|c|c|c|c|c|}
\hline Sample Period & $\mathrm{pH}$ & TDS (mg/L) & $\operatorname{COND}(\mu \mathrm{S} / \mathrm{cm})$ & TEMP $\left({ }^{\circ} \mathrm{C}\right)$ & COD $(\mathrm{mg} / \mathrm{L})$ & BOD (mg/L) & Oil \& $\mathrm{G}(\mathrm{mg} / \mathrm{L})$ & Chlor $(\mathrm{mg} / \mathrm{L})$ \\
\hline \multicolumn{9}{|l|}{ December } \\
\hline W1 & 8.2 & 1961.3 & 3922.3 & 30.7 & 383.0 & 120.3 & 10.7 & 7092.7 \\
\hline W2 & 8.3 & 1903.3 & 3805.3 & 31.0 & 136.7 & 45.7 & 13.3 & 5646.3 \\
\hline W3 & 7.5 & 141.7 & 283.0 & 29.3 & 180.3 & 65.7 & 70.0 & 2449.0 \\
\hline \multicolumn{9}{|l|}{ January } \\
\hline W1 & 8.3 & 1960.3 & 3920.0 & 31.0 & 386.0 & 123.3 & 12.5 & 7097.7 \\
\hline W2 & 8.3 & 1904.7 & 3809.7 & 31.3 & 137.7 & 45.0 & 13.7 & 5649.3 \\
\hline W3 & 7.6 & 142.3 & 285.0 & 29.3 & 181.7 & 66.7 & 71.7 & 2449.7 \\
\hline \multicolumn{9}{|l|}{ February } \\
\hline W1 & 8.5 & 1956.0 & 3912.3 & 29.0 & 392.3 & 131.0 & 10.3 & 7100.3 \\
\hline W2 & 8.7 & 1902.0 & 3803.7 & 30.0 & 142.3 & 53.3 & 11.3 & 5649.7 \\
\hline W3 & 8.1 & 140.7 & 281.3 & 29.5 & 192.7 & 69.0 & 70.3 & 2447.3 \\
\hline \multicolumn{9}{|l|}{ March } \\
\hline W1 & 8.3 & 1953.0 & 3906.0 & 29.5 & 405.0 & 127.0 & 11.7 & 7104.7 \\
\hline W2 & 8.5 & 1899.7 & 3799.3 & 30.3 & 141.3 & 50.7 & 14.0 & 5652.7 \\
\hline W3 & 8.0 & 140.3 & 279.7 & 29.7 & 194.7 & 68.7 & 68.0 & 2448.3 \\
\hline Mean & 8.2 & 1333.8 & 2667.3 & 30.1 & 239.5 & 80.5 & 31.5 & 5065.6 \\
\hline
\end{tabular}

W1 is water samples from downstream, $W 2$ water samples from midstream, $W 3$ water samples from upstream, TDS total dissolved solids, COND conductivity, TEMP temperature, $C O D$ chemical oxygen demand, BOD biological oxygen demand, Oil \& $G$ oil and grease, Chlor chloride 
Table 2 Correlation coefficients of the physiochemical parameters measured from water sample of Butuah Lagoon

\begin{tabular}{|c|c|c|c|c|c|c|c|c|}
\hline & TDS & $\mathrm{pH}$ & COND & TEMP & COD & BOD & Chlor & Oil \& G \\
\hline TDS & 1.000 & & & & & & & \\
\hline $\mathrm{PH}$ & 0.078 & 1.000 & & & & & & \\
\hline COND & 1.000 & 0.078 & 1.000 & & & & & \\
\hline TEMP & 0.511 & -0.122 & 0.511 & 1.000 & & & & \\
\hline COD & 0.362 & 0.195 & 0.362 & -0.139 & 1.000 & & & \\
\hline BOD & 0.306 & 0.176 & 0.306 & -0.211 & 0.995 & 1.000 & & \\
\hline Chlor & 0.960 & 0.123 & 0.960 & 0.398 & 0.607 & 0.558 & 1.000 & \\
\hline Oil \& G & -0.998 & -0.079 & -0.998 & $-\mathbf{0 . 5 0 3}$ & -0.362 & -0.306 & -0.958 & 1.000 \\
\hline
\end{tabular}

Bolded values are statistically significant $(p<0.05)$

$T D S$ total dissolved solids, COND conductivity, TEMP temperature, $C O D$ chemical oxygen demand, $B O D$ biological oxygen demand, Chlor chloride, Oil \& $G$ oil and grease

Mean oil and grease concentration was $31.5 \pm 4.6 \mathrm{mg} /$ L (Table 1) and was negatively correlated with temperature, BOD and all the other parameters (Table 2). The high concentration of oil and grease was not surprising as the industries around the lagoon include oil companies and automobile repair artisans and was above the recommended limits of 10 and $20 \mathrm{mg} / \mathrm{L}$ for freshwater and marine life, respectively [38]. Aquatic organisms, particularly at the juvenile life stages are likely to be affected by the presence of oil and grease. The oil layer formed could, for example, affect photosynthesis by decreasing light penetration, and decrease the amount of dissolved oxygen and temperature, which could affect the survival of several aquatic species. The effect could also include killing through coating, asphyxiation and contact poisoning [22].

What is the level of $\mathrm{Cd}, \mathrm{Pb}, \mathrm{As}, \mathrm{Zn}, \mathrm{Fe}, \mathrm{Hg}$, and $\mathrm{Cu}$ in water, sediment and fish samples from Butuah Lagoon?

The concentrations of heavy metals were compared against standards such as the Interim Freshwater Sediment Quality Guidelines (ISQG) of the Canadian Council of Ministers of the Environment, United States Environmental Protection Agency (US EPA), the Food Safety Authority of Ireland and the World Health Organization.

\section{Cadmium $(C d)$}

Cadmium can mainly be found in the earth's crust but concentration could increase through deposition of manures, phosphate fertilizer and sewage sludge into the Lagoon [23, 24]. Mean $\mathrm{Cd}$ concentration in the water $(0.32 \pm 0.005 \mathrm{mg} / \mathrm{L})$ and sediment $(5.0 \pm 0.5 \mathrm{mg} / \mathrm{kg})$ were above the standard compared [25, 26] (Tables 3, 4). The mean concentration in fish was, however, below the detectable limit, with the highest concentration of $0.97 \mathrm{mg} /$ kg measured. [23, 24, 27].

\section{Lead $(\mathrm{Pb})$}

The major anthropogenic sources of $\mathrm{Pb}$ are in lead-acid storage batteries particularly for motor vehicles and leadakyl compounds added to petrol, non-ferrous metal smelting and refining, natural manufacturing processes and dumping of sewage sludge [24, 28].Mean concentrations of $\mathrm{Pb}$ in the water $(0.244 \pm 0.018 \mathrm{mg} \mathrm{L})$ and sediment $(39.2 \pm$ $5.1 \mathrm{mg} \mathrm{kg}$ ) were above the recommended levels for each medium $[25,26]$. In both media the highest concentration of $\mathrm{Pb}$ was recorded at the midstream (Table 3 ). The mean concentrations recorded in fish $(4.6 \pm 0.6 \mathrm{mg} / \mathrm{kg})$ was also above the level recommended for human consumption [29]. The proximity of the lagoon, particularly the midstream, to an industrial complex, auto mechanic shops and a large oil storage facility could explain the reason for the relatively higher levels of $\mathrm{Pb}$ recorded during the sampling period [30].

\section{Arsenic (As)}

The concentration of As in the sediment ranged between 51.07 and $120.37 \mathrm{mg} / \mathrm{kg}$ during the sampling period, and significantly differed among the stations (Tables 3,4 ), with mean $(84.7 \pm 3.2 \mathrm{mg} / \mathrm{kg})$ highly above the recommended level [25]. The range of As in the muscles of fish during the sampling period was between 1.93 and $8.13 \mathrm{mg} / \mathrm{kg}$ with mean of $(5.0 \pm 0.3 \mathrm{mg} / \mathrm{kg})$ which was high above the provisional maximum tolerable daily intake [31]. The concentrations declined generally from December to March. Arsenic was not detected in water samples from the lagoon during the sampling period. The presence of wood processing companies around the lagoon may account for the high levels of As in the sediments as it is used as a wood preservative in pressure-treated wood [32]. 
Table 3 Results from Linear Mixed Model comparing concentration (mean \pm standard error) of heavy metals in sediments and water of Butuah Lagoon at the three sampled stations

\begin{tabular}{|c|c|c|c|c|c|c|}
\hline \multirow[t]{2}{*}{ Element } & \multirow[t]{2}{*}{ Medium } & \multicolumn{3}{|c|}{ Concentration $(\mathrm{mg} / \mathrm{kg}$ and $\mathrm{mg} / \mathrm{L}$ respectively) } & \multirow[t]{2}{*}{$F$} & \multirow[t]{2}{*}{$p$} \\
\hline & & Downstream & Midstream & Upstream & & \\
\hline As & Sediment & $94 \pm 6$ & $94 \pm 3$ & $67 \pm 3$ & 24 & 0.001 \\
\hline \multirow[t]{2}{*}{$\mathrm{Fe}$} & Sediment & $1517 \pm 101$ & $1771 \pm 49$ & $1839 \pm 59$ & 3 & 0.094 \\
\hline & Water & $0.83 \pm 0.20$ & $0.28 \pm 0.03$ & $1.27 \pm 0.17$ & 36 & 0.001 \\
\hline \multirow[t]{2}{*}{$\mathrm{Cu}$} & Sediment & $18.6 \pm 8.5$ & $60.6 \pm 4.7$ & $5.8 \pm 0.6$ & 85 & 0.001 \\
\hline & Water & $0.04 \pm 0.01$ & $0.04 \pm 0.01$ & $0.033 \pm 0.006$ & 49 & 0.001 \\
\hline \multirow[t]{2}{*}{$\mathrm{Zn}$} & Sediment & $146.3 \pm 93.3$ & $228.8 \pm 74.8$ & $35.1 \pm 35.3$ & 16 & 0.004 \\
\hline & Water & $0.30 \pm 12.00$ & $0.15 \pm 0.03$ & $0.20 \pm 0.32$ & 2 & 0.181 \\
\hline \multirow[t]{2}{*}{$\mathrm{Pb}$} & Sediment & $32.7 \pm 13.0$ & $77.8 \pm 5.7$ & $7.6 \pm 1.7$ & 62 & 0.001 \\
\hline & Water & $0.29 \pm 0.03$ & $0.28 \pm 0.29$ & $0.17 \pm 0.02$ & 60 & 0.001 \\
\hline \multirow[t]{2}{*}{$\mathrm{Cd}$} & Sediment & $3.7 \pm 1.9$ & $7.7 \pm 1.8$ & $3.7 \pm 3.8$ & 2 & 0.142 \\
\hline & Water & $0.037 \pm 0.010$ & $0.037 \pm 0.01$ & $0.22 \pm 0.005$ & 7 & 0.002 \\
\hline $\mathrm{Hg}$ & Sediment & $0.004 \pm 0.007$ & $0.148 \pm 0.008$ & $0.005 \pm 0.008$ & - & - \\
\hline
\end{tabular}

\begin{tabular}{|c|c|c|c|c|}
\hline \multirow[t]{2}{*}{ Element } & \multirow[t]{2}{*}{ Medium } & \multicolumn{3}{|c|}{ Mean concentration difference \pm Standard error } \\
\hline & & $\mathrm{S} 1-\mathrm{S} 2$ & S1-S3 & $\mathrm{S} 2-\mathrm{S} 3$ \\
\hline As & Sediment & $0.267 \pm 4.5$ & $27.4 \pm 4.5$ & $27.1 \pm 4.5$ \\
\hline \multirow[t]{2}{*}{$\mathrm{Fe}$} & Sediment & $-253.3 \pm 126.4$ & $-322.0 \pm 126.4$ & $-68.4 \pm 126.4$ \\
\hline & Water & $0.55 \pm 0.1$ & $-0.437 \pm 0.1$ & $-0.987 \pm 0.1$ \\
\hline \multirow[t]{2}{*}{$\mathrm{Cu}$} & Sediment & $-42.1 \pm 4.4$ & $12.7 \pm 4.4$ & $54.8 \pm 4.4$ \\
\hline & Water & $0.002 \pm 0.001$ & $0.011 \pm 0.001$ & $0.009 \pm 0.001$ \\
\hline \multirow[t]{2}{*}{$\mathrm{Zn}$} & Sediment & $-82.6 \pm 34.8$ & $111.2 \pm 34.8$ & $193.8 \pm 34.8$ \\
\hline & Water & $0.144 \pm 0.077$ & $0.094 \pm 0.077$ & $-0.050 \pm 0.077$ \\
\hline \multirow[t]{2}{*}{$\mathrm{Pb}$} & Sediment & $-45.1 \pm 6.4$ & $25.1 \pm 6.4$ & $70.2 \pm 6,4$ \\
\hline & Water & $0.009 \pm 0.012$ & $0.122 \pm 0.012$ & $0.113 \pm 0.012$ \\
\hline \multirow[t]{2}{*}{$\mathrm{Cd}$} & Sediment & $-4.0 \pm 2.1$ & $-0.7 \pm 2.1$ & $4.0 \pm 2.1$ \\
\hline & Water & $0.000 \pm 0.004$ & $0.015 \pm 0.004$ & $0.015 \pm 0.004$ \\
\hline
\end{tabular}

Table 4 Contrasts from Linear Mixed Model comparing concentration of heavy metals in water and sediments of Butuah lagoon collected at three stations

Bold values are significant at $p<0.05$. Bonferroni correction was used to adjust the significance level

S1 downstream, $S 2$ midstream, S3 upstream
Iron $(\mathrm{Fe})$

Mean concentration $(0.80 \pm 0.109 \mathrm{mg} / \mathrm{L})$ of iron in the water was below the levels recommended for freshwater aquatic life but above domestic water supplies [26], with the upstream having the highest (Tables 3,4). The concentration ranged between 1209.00 and $2147.30 \mathrm{mg} / \mathrm{kg}$ in the sediment (Tables 3, 4) and between 33.17 and $210.06 \mathrm{mg} / \mathrm{kg}$ in the fish. The concentrations of Fe could be attributed to background levels, as Fe-rich chlorite is commonly identified in subsurface estuarine and other marginal marine successions [33].

Mercury $(\mathrm{Hg})$

Samples of sediment collected for $\mathrm{Hg}$ recorded lower concentrations during the sampling period, with no $\mathrm{Hg}$ 
Table 5 Enrichment factor of heavy metals in the surface sediments of three stations of Butuah Lagoon with Fe as normalization element

\begin{tabular}{|c|c|c|c|c|c|c|}
\hline \multirow[t]{2}{*}{ Station } & \multicolumn{6}{|c|}{ Enrichment factor } \\
\hline & As & $\mathrm{Cu}$ & $\mathrm{Zn}$ & $\mathrm{Pb}$ & $\mathrm{Cd}$ & $\mathrm{Hg}$ \\
\hline Downstream & 650.08 & 22.01 & 72.51 & 63.80 & 1347.21 & 2.82 \\
\hline Midstream & 555.48 & 61.65 & 97.23 & 130.22 & 2424.88 & 8.40 \\
\hline Upstream & 379.84 & 5.68 & 14.34 & 12.20 & 1131.67 & 2.60 \\
\hline Mean in the lagoon & 528.47 & 29.78 & 61.36 & 68.74 & 1634.59 & 4.61 \\
\hline
\end{tabular}

A pre-industrial baseline concentration of heavy metals for the area could not be obtained; therefore, the recommended composition of the upper continental crust by Rudnick and Gao [17] was used

being detected during some sampling periods. The mean concentration $(0.008 \pm 0.001 \mathrm{mg} / \mathrm{kg})$ was, therefore, below the highest concentration level recommended by Canadian Council of Ministers of the Environment 2001 standards (Tables 3,4). The concentration recorded in the fish samples was also far below the standard recommended by the Food Safety Authority of Ireland [34]. It ranged between 0.008 and $0.014 \mathrm{mg} / \mathrm{kg}$, with the highest being recorded in February. Mercury was not detected in the water samples.

\section{Copper (Cu)}

The mean concentrations of $\mathrm{Cu}$ in the water $(0.04 \pm 0.003 \mathrm{mg} / \mathrm{L})$, sediments $(28.3 \pm 4.1 \mathrm{mg} / \mathrm{kg})$ and fish $(2.1 \pm 0.5 \mathrm{mg} / \mathrm{kg})$ samples were below the various standards compared [25, 26, 29].

What is the degree of heavy metal pollution in the sediment as indicated by assessment index?

\section{Enrichment factor $(E F)$}

The enrichment factor values of the metals studied (based on $\mathrm{Fe}$ as the normalizing metal) are presented in Table 5. The highest EF value was recorded for $\mathrm{Cd}$ and was throughout the three stations, with midstream having the highest. This could be attributed to the fact that cadmium ions are known to be most mobile among other metals [35]. The lowest EF values for all stations were recorded for $\mathrm{Hg}$. The $\mathrm{EF}$ values were all found to be $>10$ except for $\mathrm{Hg}$ at all the stations, indicating influence of anthropogenic activities at the stations. The sediments for the entire system show high anthropogenic inputs from the surrounding areas with the order of average $\mathrm{EF}$ values from the highest to the lowest being $\mathrm{Cd}>\mathrm{As}>\mathrm{Pb}>\mathrm{Zn}>\mathrm{Cu}>\mathrm{Hg}$ (Table 5).

\section{Contamination factor, degree of contamination and PLI}

All stations were found to have a very high contamination of $\mathrm{As}$ and $\mathrm{Cd}$ while low contamination of $\mathrm{Fe}, \mathrm{Cu}$ and $\mathrm{Pb}$ were observed in almost all the three stations (Table 6). For the entire lagoon, the contamination levels of $\mathrm{As}$ and $\mathrm{Cd}$ could be classified as very high; $\mathrm{Cu}, \mathrm{Zn}$, and $\mathrm{Pb}$ concentration could be categorized as moderate, while $\mathrm{Fe}$ and $\mathrm{Hg}$ could be considered as low concentration (Table 6). The modified degree of contamination $\left(m C_{\mathrm{d}}\right)$ values indicate significant anthropogenic impact in all the sediments, with the midstream having an extremely high degree of contamination (Table 6). As also shown (Table 6), the midstream and downstream had pollution load indexes (PLI) $>1$, indicating a deterioration of sediment quality. The entire lagoon also showed a progressive deterioration with $\mathrm{PLI}_{\mathrm{E}}$ of 1.32.

\section{Geo-accumulation index}

The geo-accumulation indexes varied from metal to metal for the different sampled stations (Table 7). $\mathrm{Fe}, \mathrm{Cu}$ and $\mathrm{Hg}$ remain unpolluted in at least two of the sampled stations, suggesting that their concentration in the sediments is in background value. For the entire system the Igeo values calculated according to the Muller scale indicate that $\mathrm{Cd}$ was strongly to extremely polluted, As moderately to strongly polluted, $\mathrm{Zn}$ and $\mathrm{Pb}$ as unpolluted to moderately polluted, and $\mathrm{Fe}$ and $\mathrm{Cu}$ as unpolluted in the sediment (Table 7). The strong to extremely polluted nature of $\mathrm{Cd}$ is alarming as this has the potential to displace $\mathrm{Zn}$ from many zinc-coating enzymes [24]. The toxicological importance of As is partly due to its chemical similarity with phosphorous which means As can disrupt metabolic pathways involving the latter [36]. These will, therefore, have deleterious effects on humans who are exposed to such high levels. 
Table 6 Contamination factor, degree of contamination and Tomlinson's pollution load index of heavy metals in the surface sediments of three stations of Butuah lagoon

\begin{tabular}{|c|c|c|c|c|c|c|c|c|c|c|}
\hline \multirow[t]{2}{*}{ Station } & \multicolumn{7}{|c|}{ Contamination factor } & \multirow[t]{2}{*}{$\mathrm{C}_{d}$} & \multirow[t]{2}{*}{$m C_{\mathrm{d}}$} & \multirow[t]{2}{*}{ PLI } \\
\hline & As & $\mathrm{Fe}$ & $\mathrm{Cu}$ & $\mathrm{Zn}$ & $\mathrm{Pb}$ & $\mathrm{Cd}$ & $\mathrm{Hg}$ & & & \\
\hline Downstream & 19.57 & 0.03 & 0.66 & 2.18 & 1.92 & 40.56 & 0.09 & 65.01 & 9.29 & 1.28 \\
\hline Midstream & 19.51 & 0.04 & 2.17 & 3.42 & 4.57 & 85.19 & 0.30 & 115.20 & 16.46 & 2.48 \\
\hline Upstream & 13.86 & 0.04 & 0.21 & 0.52 & 0.45 & 41.30 & 0.10 & 56.48 & 8.07 & 0.72 \\
\hline Mean in the lagoon & 17.65 & 0.04 & 1.01 & 2.04 & 2.31 & 55.68 & 0.16 & 78.90 & 11.27 & 1.49 \\
\hline
\end{tabular}

A pre-industrial baseline concentration of heavy metals for the area could not be obtained; therefore, the recommended composition of the upper continental crust by Rudnick and Gao [17] was used

$\mathrm{C}_{d}$ degree of contamination, $m C_{\mathrm{d}}$ modified degree of contamination, PLI Tomlinson's pollution load index

Table 7 The Geo-accumulation Index ( $\left.I_{\text {geo }}\right)$ of heavy metals in the surface sediments of three stations of Butuah lagoon

\begin{tabular}{|c|c|c|c|c|c|c|c|}
\hline \multirow[t]{2}{*}{ Station } & \multicolumn{7}{|c|}{ Geo-accumulation index $\left(I_{\text {geo }}\right)$} \\
\hline & As & $\mathrm{Fe}$ & $\mathrm{Cu}$ & $\mathrm{Zn}$ & $\mathrm{Pb}$ & $\mathrm{Cd}$ & $\mathrm{Hg}$ \\
\hline Downstream & 3.71 & -5.64 & -1.18 & 0.54 & 0.36 & 4.76 & -4.14 \\
\hline Midstream & 3.70 & -5.42 & 0.53 & 1.19 & 1.61 & 5.83 & -2.35 \\
\hline Upstream & 3.21 & -5.36 & -2.85 & -1.52 & -1.75 & 4.78 & -3.98 \\
\hline Mean in the lagoon & 3.54 & -5.47 & -1.17 & 0.07 & 0.07 & 5.12 & -3.49 \\
\hline
\end{tabular}

A pre-industrial baseline concentration of heavy metals for the area could not be obtained; therefore, the recommended composition of the upper continental crust by Rudnick and Gao [17] was used

\section{Conclusion}

We assessed the pollution status of the Butuah Lagoon using different media within the ecosystem. The results obtained indicated higher physiochemical parameters of the lagoon including high TDS, BOD and oil and grease. Concentrations of $\mathrm{Pb}, \mathrm{Zn}, \mathrm{As}, \mathrm{Cd}$ in sediments; $\mathrm{Pb}, \mathrm{Zn}, \mathrm{Cd}$ in water samples, and $\mathrm{Pb}$ in the muscle of the fish were higher than the permissible limits. The mean values recorded for heavy metals and the other physicochemical parameters along the Butuah Lagoon during the sampling indicated a general trend of anthropogenic pollution in and around the lagoon, particularly around the midstream.

Pollution in the Butuah Lagoon has varied consequences on the biodiversity and the numerous users of the lagoon. The rich biodiversity of the ecosystem could be reduced and some species even driven to local extinction. The potential for the heavy metals to biomagnify along the food chain also calls for serious concern due to the implications on human health. Heavy metals are known to cause damage to major organs in humans such as the kidney, heart, liver and brain upon chronic exposure. There is, therefore, the need to embark on periodic monitoring activities of the Lagoon and possible regular checks of the treatment systems of the surrounding industries that discharge waste into the lagoon. Public education of the significance of the lagoon is also needed. These measures will ensure the protection of the lagoon, its aquatic life and their human dependents. A comprehensive management plan for the protection of the Butuah Lagoon might help also prevent or reduce this pollution.

We took measurements for 4 months at three sampling stations. Future research could be longer, at least 6 months, with numerous sampling stations and other fish species to provide more information about the status of the lagoon. The assessment of heavy metals in the fish species could also be done using the gills, kidney and liver as these are potential sinks for heavy metals. This research goes a long way to provide valuable information that is missing. Fish, Tilapia especially is a very important ingredient in the Ghanaian meal. The results thus present the reader with information on the levels of heavy metals in the fish that is usually consumed. This information will also appeal to the wide audience and institutions responsible to regulate the introduction of waste into Lagoons knowing that the trend in levels of contamination varies at different climatic/environmental conditions.

Acknowledgments This manuscript is part of an MSc project of the first author. He, therefore, would like to thank his parents (Mr. and Mrs. Christopher T. Odjer-Bio), Mrs Felicia N. A. Odjer-Bio, and Mr. Fritz Osei-Amoah for their financial support. The authors would also like to thank Mr. N. Jackson-Mensah and Mr. K. A. Obirikorang, Mr. 
Bassaw of the Minerals Commission, the quality assurance staff of West African Mills Company, and Ms. Ephraim Arthur, for their support with the data collection, laboratory work and analysis of some data as well as Dr. Helen La Throbe for proofreading this manuscript.

Open Access This article is distributed under the terms of the Creative Commons Attribution License which permits any use, distribution, and reproduction in any medium, provided the original author(s) and the source are credited.

\section{References}

1. Aderinola, O.J., Clarke, E.O., Olarinmoye, O.M., Kusemiju, V., Anatekhai, M.A.: Heavy metals in surface water, sediments, fish and Perwinklesof Lagos Lagoon. Am.-Eurasian J. Agric. Environ. Sci. 5(5), 609-617 (2009)

2. Kennish, M., Pearl, H. (eds.): Coastal Lagoons: Critical Habitats of Environmental Change. Taylor and Francis, Florida (2010)

3. Millennium Ecosystem Assessment: Ecosystems and Human Well-being: Wetlands and Water Synthesis. World Resources Institute, Washington, DC (2005)

4. Nasehi, F., Hassani, A., Monavvari, M., Karbassi, A., Khorasani, N.: Evaluating the metallic pollution of riverine water and sediments: a case study of Aras River. Environ. Monit. Assess. 185(1), 197-203 (2013)

5. Aissa, L., Kéloufi, B.: Determining the heavy metal pollution in Mascara (Algeria) by using Casuarina equisetifolia. Ecologia Balkanica 4(1), 1-7 (2012)

6. Saha, P., Hossain, M.: Assessment of heavy metal contamination and sediment quality in the Buriganga River, Bangladesh. In: 2nd International Conference on Environmental Science and Technology, IPCBEE, Singapore 2011, pp. 26-28

7. Kennish, M., Livingston, R., Raffaelli, D., Reise, K.: Environmental future of estuaries. In: Polunin, N. (ed.) Aquatic Ecosystems: Trends and global prospects, pp. 188-208. Cambridge University Press, Cambridge (2008)

8. Ansong, M.: Determination of willingness to pay for the conservation of Butuah Lagoon using Contingent Valuation Method. KNUST (2007)

9. Coastal Resources Center- Ghana/Friends of the Nation: Rapid biodiversity assessment on the Essei and Butuah Lagoons and Whin River Estuary in the Sekondi-Takoradi Metropolis of the Western Region of Ghana. Coastal Resource Center in Partnership with Friends of the Nation on the Hen Mpoano Initiative in Ghana. Technical Report. http://www.crc.uri.edu/download/ GH2009STMA001_508.pdf (2010). Accessed 17 Dec 2010

10. American Public Health Association: Standard Methods for the Examination of Water and Wastewater, 18th edn. American Public Health Association, Washington, DC (1992)

11. Motsara, M., Roy, R.N.: Guide to Laboratory Establishment for Plant Nutrient Analysis, vol. 19. Food and Agriculture Organization, Rome (2008)

12. Sinex, S., Helz, G.: Regional geochemistry of trace elements in Chesapeake Bay sediments. Environ. Geol. 3(6), 315-323 (1981)

13. Abrahim, G.M.S., Parker, R.J.: Assessment of heavy metal enrichment factors and the degree of contamination in marine sediments from Tamaki Estuary, Auckland, New Zealand. Environ. Monit. Assess. 136(1-3), 227-238 (2008). doi:10.1007/ s10661-007-9678-2

14. Hakanson, L.: An ecological risk index for aquatic pollution control. A sedimentological approach. Water Res. 14(8), 975-1001 (1980)

15. Tomlinson, D., Wilson, J., Harris, C., Jeffrey, D.: Problems in the assessment of heavy-metal levels in estuaries and the formation of a pollution index. Helgoländer Meeresuntersuchungen 33(1-4), 566-575 (1980)

16. Müller, G.: Index of geoaccumulation in sediments of the Rhine River. GeoJournal 2, 108-118 (1969)

17. Rudnick, R., Gao, S.: Composition of the continental crust. Treatise Geochem. 3, 1-64 (2003)

18. Government of Mississippi: State of Mississippi Water Quality Criteria for Intrastate, Interstate, and Coastal Waters. Mississippi Department of Environmental Quality, Jackson (2007)

19. FAO: Cultured aquatic species information programme-Oreochromis niloticus. In: Rakocy, J.E. (ed.) In FAO Fisheries and aquaculture department. (online). http://www.fao.org/fishery/cul turedspecies/Oreochromis_niloticus/en (2005). Accessed 18 Jan 2011

20. Chapman, D.V.: Water quality assessments: a guide to the use of biota, sediments and water in environmental monitoring. Cambridge University Press, Cambridge (1996)

21. Barron, J, Ashton, C: The effect of temperature on conductivity measurement. TSP, 7, Issue 3.http://www.camlabworld.com/ori ginalimages/sitefiles/Tech_papers/TempCondMeas.pdf (2005). Accessed 4 Nov 2013

22. Carr, G, Neary, J.P.: Water quality for ecosystem and human health. A Report by United Nations Environment Programme Global Environment Monitoring System (GEMS)/Water programme. Ontario, Canada, pp. 132 http://www.env-edu.gr/Docu ments/Water\%20Quality\%20For\%20Ecosystems\%20and\% 20Human\%20Health.pdf (2006). Accessed 5 Dec 2012

23. Alloway, B., Steinnes, E.: Anthropogenic additions of cadmium to soils. In: McLaughlin, M., Singh, B. (eds.) Cadmium in Soils and Plants, pp. 97-123. Kluwer Academic Publishers, Dordrecht (1999)

24. O'Neill, P.: Environmental Chemistry, 2nd edn. Chapman and Hall, London (1993)

25. Canadian Council of Ministers of the Environment: Canadian sediment quality guidelines for the protection of aquatic life: summary tables. http://www.elaw.org/system/files/sediment_sum mary_table.pdf (2001). Accessed 03 Apr 2012

26. United States Environmental Protection Agency: Quality criteria for water 1986. Washington, DC: Office of water regulations and standards. http://water.epa.gov/scitech/swguidance/standards/cri teria/aqlife/upload/2009_01_13_criteria_goldbook.pdf (1986). Accessed 20 Aug 2013

27. Morrow, H.: Cadmium and cadmium alloys. In: Kirk-Othmer Encyclopedia of Chemical Technology, pp. 471-507. Wiley, New Jersey (2001)

28. United Nations Environment Programme: Final review of scientific information on lead. Chemicals branch, DTIE. http://www. environmentalhealthnews.org/ehs/news/2013/pdf-links/UN\% 202010\%20report.pdf (2010). Accessed 17 Jul 2012

29. Nauen, C.E.: Compilation of legal limits for hazardous substances in fish and fishery products. FAO Fisheries Circular, (764). $102 \mathrm{p}$ http://www.fao.org/docrep/014/q5114e/q5114e.pdf (1983). Accessed 10 Jun 2013

30. Hounkpatin, A.S., Edorh, A.P., Sèzonlin, M., Guédénon, P., Elégbédé, B., Boni, G., Dougnon, V., Montcho, S., Kéké, E., Boko, M.: Pollution of aquatic ecosystems by heavy metals at Ganviés's lacustrine city (Benin). Int. Res. J. Biotechnol. 3(6), 81-87 (2012)

31. World Health Organisation: Safety evaluation of certain food additives and contaminants. Who additive series, 44. Nos 965-986 on INCHEM. http://www.who.int/foodsafety/chem/ jecfa/publications/monographs/en/index.html (2000). Accessed 15 Feb 2013

32. Hill, M.K.: Understanding environmental pollution. Cambridge University Press, Cambridge (1997)

33. Dowey, P.J., Hodgson, D.M., Worden, R.H.: Pre-requisites, processes, and prediction of chlorite grain coatings in petroleum 
reservoirs: a review of subsurface examples. Mar. Pet. Geol. 32(1), 63-75 (2012)

34. Food Safety Authority of Ireland: Legislation on Chemical Contaminants. Dublin: Food safety authority of Ireland. www. fsai.ie/WorkArea/DownloadAsset.aspx?id=9278 (2009). Accessed 11 Nov 2013

35. Kabata-Pendias, A.: Trace Elements in Soils and Plants. CRC Press, Boca Raton (2010)

36. Alloway, B., Ayres, D.C.: Chemical Principles of Environmental Pollution, 2nd edn. Blackie Academic and Professional, London (1997)

37. Birge, W.J., Black, J.A., Westerman, A.G., Short, T.M., Taylor, S.B., Bruser, D.M., Wallingford: Recommendations on numerical values for regulating iron and chloride concentrations for the purpose of protecting warm water species of aquatic life in the Commonwealth of Kentucky. Memorandum of Agreement No. 5429. Kentucky Natural Resources and Environmental Protection Cabinet. Lexington, KY. (1985)

38. DPR: Guidelines and Standards for Petroleum Industry in Nigeria. The Department of Petroleum Resources, The Federal Ministry of Petroleum and Mineral Resources (1991)

39. Evans, M., Frick, C.: The effects of road salts on aquatic ecosystems. NWRI Contribution Series No. 01-000. National Water Research Institute, Saskatoon, Saskatchewan (2001) 